\title{
Phycoremediation and the Potential of Sustainable Algal Biofuel Production using Wastewater
}

\author{
${ }^{\mathbf{1}}$ Adel A. Fathi, ${ }^{2,3}$ Mohamed M. Azooz and ${ }^{3}$ Mohamed A. Al-Fredan \\ ${ }^{1}$ Department of Botany and Microbiology, \\ Faculty of Science, El-Minia University, 6159-El-Minia, Egypt \\ ${ }^{2}$ Department of Botany, Faculty of Science, South Valley University, Qena, Egypt \\ ${ }^{3}$ Department of Biological Sciences, \\ College of Science, King Faisal University, Al-Hassa, Saudi Arabia
}

Received 2012-01-06, Revised 2012-11-10; Accepted 2013-04-12

\begin{abstract}
Wastewater remediation by microalgae is an eco-friendly process with no secondary pollution as long as the biomass produced is reused and allows efficient nutrient recycling. This study was undertaken to evaluate the remediation of wastewater by the green alga Chlorella vulgaris and the potential of these alga (biomass) to produce sustainable biofuel. The results shows that the cultivation of green alga Chlorella vulgaris on wastewater has a positive effect on removal the major inorganic elements form the wastewater. Biodiesel can be produced from Chlorella vulgaris. The Chlorella vulgaris can be used for remediation of wastewater and the producing biomass can be used as source of renewable energy.
\end{abstract}

Keywords: Phycoremedation, Water, Algae, Biofuel

\section{INTRODUCTION}

Algae are important bioremediation agents and are already being used by many wastewater facilities. The potential for algae in wastewater remediation is however much wider in scope than its current role. The release of wastewater poses serious environmental challenges to the receiving water bodies (De-Bashan and Bashan, 2010). The major effect of releasing wastewater rich in organic compounds and inorganic chemicals such as phosphates and nitrates is mainly eutrophication (Pizarro et al., 2006; Munoz and Guieysse, 2008; Mulbry et al., 2008; Godos et al., 2009). This is a global problem that can be solved by the use of microalgae whereby the wastewater is used as feed for microalgal growth. The advantage is that while the microalgae will be removing excess nutrients in the wastewater, there will be concomitant accumulation of biomass for downstream processing (Chinnasamy et al., 2010). The use of a wide range of microalgae such as Chlorella, Scenedesmus, Phormidium, Botryococcus, Chlamydomonas and Spirulina for treating wastewater has been reported and efficacy of this method is promising (Olguin, 2003; Chinnasamy et al., 2010; Kong et al., 2010; Pittman et al., 2010; Stephens et al., 2010).

With global shortages of fossil fuels, especially oil and natural gas, a major focus has developed worldwide on renewable biofuel production. Algae, particularly green unicellular microalgae have been proposed for a long time as a potential renewable fuel source (Oswald and Golueke, 1960). Microalgae have been estimated to have higher biomass productivity than plant crops in terms of land area required for cultivation, are predicted to have lower cost per yield and have the potential to reduce green house emissions through the replacement of fossil fuels (Brune et al., 2009; Chisti, 2008; Dismukes et al., 2008).

The use of microalgae is desirable since they are able to serve a dual role of bioremediation of wastewater as well as generating biomass for biofuel production with concomitant

Correspondence Author: Adel A. Fathi, Department of Botany and Microbiology, Faculty of Science, El-Minia University, 6159-El-Minia, Egypt Tel: 00201223246344 
carbon dioxide sequestration (Olgun et al., 2003; Mulbry et al., 2008; Rawat et al., 2011). In addition, wastewater remediation by microalgae is an eco-friendly process with no secondary pollution as long as the biomass produced is reused and allows efficient nutrient recycling (Godos et al., 2009). This study was undertaken with the aim to evaluate the remediation of waste water by the green alga Chlorella vulgaris and the potential of these alga (biomass) to produced sustainable biofuel.

\section{MATERIALS AND METHODS}

\subsection{Wastewater Collection}

The wastewaters used in the study, were collected (in April 2010) from four different sources of wastewater on Al-Hassa area, Saudi Arabia.

\subsection{Physico-Chemical Characteristics of Wastewaters}

$\mathrm{pH}$, conductivity, total dissolved salts and Dissolved oxygen of the wastewater were measured in location. $\mathrm{pH}$ was measured using a $\mathrm{pH}$ meter $(370 \mathrm{pH}$ meter Jenway, UK), conductivity and total dissolved salts using a calibrated Conductivity Meter (470 Conductivity meter, Jenway, UK). Dissolved oxygen was measured according to the Winkler method (Strickland and Parsons, 1972). Total alkalinity, phosphate-P, nitrate-N, chloride, COD and major cations were measured according to Adams (1991). Sodium and potassium concentrations were determined photometrically by flame emission according to Golterman and Clymo (1971). The results were calculated as mean values of triplicate measurements made on each water sample from each of the four sampling stations.

\subsection{Organism and Culture Condition}

Chlorella vulgaris Beyerinck was isolated from AlAsfar Lake, Al-Hassa, Saudi Arabia. Isolation and purification were made by dilution and plating technique method. The alga was grown in $250 \mathrm{~mL}$ flasks containing $100 \mathrm{~mL}$ Kuhl (1962) medium and incubated in an illuminated incubator (Precision, USA) at $22^{\circ} \mathrm{C}$ and irradiance at $150 \mu \mathrm{mol} \mathrm{m} \mathrm{mec}^{-1}$, provided by cool white fluorescent lamps set on 14:10 h photoperiod. All cultures were shaken twice daily to prevent cells from clumping. Sterile technique was used at all times.

\subsection{Determination of Algal Growth}

Growth was measured in terms of cell number using a Haematocytometer, which was used for calculation of growth rate.

\subsection{Treatment of Wastewater Samples}

Wastewater was injected with Chlorella sp. suspension (each flask contain two liters of wastewater) with aeration and illumination for 7 days until odorless and the culture became clear and green colour appeared. The physic-chemical characteristics of wastewater before and after treatment with alga were determined as follows in previously in case of the determination of physic-chemical characteristics of wastewater. Nutrient removal rates were calculated by dividing the difference between the first day and final day concentrations by the first day concentration, then multiplied by 100 and expressed as percentage.

\subsection{Biochemical Analysis}

The anthrone method (Roe, 1955) was applied for total carbohydrate estimation using fresh material and glucose as a standard. Total lipids content was determined according to Moore and Stein (1948). Total protein was measured according to Lowry et al. (1951).

\subsection{Oil Extraction}

Algae were ground with motor and pestle as much as possible. The ground algae were dried for $20 \mathrm{~min}$ at $80^{\circ} \mathrm{C}$ in a incubator for releasing water. Hexane and ether solution (20 and $20 \mathrm{~mL}$ ) were mixed with the dried ground algae to extract oil. Then the mixture was kept for $24 \mathrm{~h}$ for settling. The extracted oil was evaporated in vaccu to release hexane and ether solutions using rotary evaporator. Mixing of catalyst and methanol: $0.25 \mathrm{~g}$ $\mathrm{NaOH}$ was mixed with $24 \mathrm{~mL}$ methanol and stirred properly for $20 \mathrm{~min}$.

\subsection{Biodiesel Production}

The mixture of catalyst and methanol was poured into the algal oil in a conical flask. The following reaction and steps were followed National Biodiesel Board.

\subsection{Transesterification}

The reaction process is called transesterification. The conical flask containing solution was shaken for $3 \mathrm{~h}$ by electric shaker at $300 \mathrm{rpm}$. After shaking the solution was kept for $16 \mathrm{~h}$ to settle the biodiesel and sediment layers clearly (Fig. 1).<smiles>[R]C(=O)OCC(C)OC([R])=O</smiles>

Fig. 1. The simplified transesterification reaction. 


\subsection{Separation of Biodiesel}

The biodiesel was separated from sedimentation by flask separator carefully. Quantity sedimeant (glycerine) was measured. Biodiesel was washed by $5 \%$ water until it was become clean. Biodiesel was dried by using dryer and finally kept under the running fan for $12 \mathrm{~h}$. Biodiesel production was measured by using measuring cylinder, $\mathrm{pH}$ was measured and stored for analysis.

\section{RESULTS AND DISCUSSION}

The chemical compositions of the four wastewaters are listed in Table 1. The data show that the $\mathrm{pH}$ values of wastewater samples I and II were in the acidic side whereas in samples III and IV in alkaline side. Samples III and IV were found to be characterized by highest total dissolved salts in comparison to other samples. It is worthy to mention that the nitrate and phosphate concentrations on sample IV were found to be high than other samples. The data also reported that the of divalent (calcium and magnesium) and monovalent cations (sodium and potassium) were relatively high at all samples, irrespective of some minor fluctuations. COD was taken in the present study as a measure of the oxygenated state and additionally the amount of organic \matter in water as well. The data of this study show that COD tended to be higher in samples III and IV (26.10 and $22.8 \mathrm{mg} \mathrm{L}^{-1}$, respectively).

Algae represent the best biological treatment for wastewater because they increase oxygen content of waters via photosynthesis. In this study, waste water was injected with an active green alga Chlorella vulgaris culture. After the incubation period the $\mathrm{pH}$ value was changed to the alkaline side. This general tendency to the alkaline side may be due to the increased photosynthetic activity of planktonic algae, or to the chemicals nature of water (Fathi et al., 2001).

Chlorella vulgaris growth in terms of cell number in the four wastewaters sample was plotted in Fig. 2. No lag phases were observed in all of the four curves, indicating that this wild-isolated algae Chlorella sp. could adapt well in all of the wastewater samples. Similar growth patterns, with exponential phases in the first 3 days followed by stationary phases in the next 6 days were present for all wastewaters, except the sample no. IV, in which the exponential phase lasted 1 day more before entering into a stationary phase. Moreover, it can be found that the algal growth was significantly enhanced in the sample no. IV. It could be due to its much higher levels of nitrogen, phosphorus and COD than the other three wastewaters (Table 1). Therefore, the results show that the sample no. IV is the best media for algal growth.

The data of Table 2 preformed that the cultivation of algae removed almost the measured parameters specially the major inorganic nutrient (phosphate and nitrate). On the other hand, oxygen content, alkalinity and COD were found to increased in compare to other tested parameters. Dissolved oxygen is an important parameter for identification of different water masses. The relatively high concentrations of dissolved oxygen recorded after algal treatment could be mainly attributed to photosynthetic activity of algae (Fathi et al., 2001). However, the highest concentrations of alkalinity may be due to the bacterial decomposition of organic substrates coming with the re-use drainage water receiving by this site (Abdel-Satar and Elewa, 2001). When the organic substrate is not available, autotrophic growth uses $\mathrm{CO}_{2}$ as the carbon source, excreting small molecular organic substances such as glycolic acid to the environment as a product of photosynthetic carbon reduction cycle (Wang et al., 2010) which is the reason why COD in effluent increased after algal cultivation. Generally the data shows that the green alga Chlorella vulgaris can be for removed the major inorganic elements form the wastewater.

In recent years, biofuel production from algae has attracted the most attention among other possible products. The recent soaring and crashing of oil prices and diminishing world oil reserves, coupled with enhanced greenhouse gases and the predicted threat of climate change, have generated renewed interest in using algae as alternative and renewable feedstock for energy production (Ramachandra et al., 2009). Algae are of great interest in the production of biofuels due to the fact that a number of species of freshwater and marine algae contain large amounts of high quality polyunsaturated fatty acids which can be produced for aquaculture operations. Algae can grow heterotrophically on cheap organic substrates, without light and under wellcontrolled cultivation conditions. The characteristics of algal oil are similar to those of fish and vegetable oils and can thus be considered as potential substitutes for the product of fossil oil (Ramachandra et al., 2009).

The data of Table 3 performed the chemical composition of tested alga. The data show that Chlorella vulgaris contain highest amount of protein and lipids in compared to the other tested biochemical parameters. Microalgae which include algal strains, diatoms and cyanobacteria have been found to contain high levels of lipids-over $30 \%$. Due to the high lipid content, these microalgal strains are of great interest in the search for sustainable sources for the production of biodiesel (Hossain and Salleh, 2008). 
Adel A. Fathi et al. / American Journal of Applied Sciences, 10 (2): 189-194, 2013

Table 1. The physical and chemical characters of the collected four wastewater samples

\begin{tabular}{|c|c|c|c|c|}
\hline Parameters & Sample I & Sample II & Sample III & Sample IV \\
\hline $\mathrm{pH}$ & 6.65 & 6.75 & 7.72 & 7.74 \\
\hline Conductivity (mS) & $2.96 \pm 0.01$ & $2.15 \pm 0.01$ & $4.56 \pm 0.01$ & $4.55 \pm 0.01$ \\
\hline T.D.S. $\left(\mathrm{g} \mathrm{L}^{-1}\right)$ & $1.77 \pm 0.01$ & $1.41 \pm 0.01$ & $3.78 \pm 0.02$ & $2.76 \pm 0.01$ \\
\hline Dissolved $\mathrm{O}_{2}\left(\mathrm{~g} \mathrm{~L}^{-1}\right)$ & $2.50 \pm 0.02$ & $4.64 \pm 0.15$ & $2.7 \pm 0.15$ & $4.00 \pm 0.02$ \\
\hline Alkalinity $\left(\mathrm{mg} \mathrm{L}^{-1}\right)$ & $52.21 \pm 0.15$ & $110 \pm 0.01$ & $99.2 \pm 0.02$ & $129 \pm 0.01$ \\
\hline Chloride $\left(\mathrm{mg} \mathrm{L}^{-1}\right)$ & $212 \pm 0.02$ & $644 \pm 0.01$ & $742 \pm 0.01$ & $538 \pm 0.15$ \\
\hline Nitrate-N $\left(\mathrm{mg} \mathrm{L}^{-1}\right)$ & $0.70 \pm 0.01$ & $0.3 \pm 0.01$ & $0.40 \pm 0.01$ & $3.74 \pm 0.02$ \\
\hline Phosphate -P $\left(\mathrm{mg} \mathrm{L}^{-1}\right)$ & $0.33 \pm 0.01$ & $0.02 \pm 0.01$ & $0.15 \pm 0.01$ & $2.75 \pm 0.15$ \\
\hline Sodium $\left(\mathrm{mg} \mathrm{L}^{-1}\right)$ & $154 \pm 0.00$ & $234 \pm 0.00$ & $402 \pm 0.00$ & $315 \pm 0.00$ \\
\hline Potassium $\left(\mathrm{mg} \mathrm{L}^{-1}\right)$ & $28.4 \pm 0.00$ & $22.0 \pm 0.00$ & $27.4 \pm 0.01$ & $21.0 \pm 0.00$ \\
\hline Calcium $\left(\mathrm{mg} \mathrm{L}^{-1}\right)$ & $176 \pm 0.00$ & $157 \pm 0.00$ & $161 \pm 0.00$ & $158 \pm 0.02$ \\
\hline $\operatorname{Magnesium}\left(\mathrm{mg} \mathrm{L}^{-1}\right)$ & $70.0 \pm 0.00$ & $68.7 \pm 0.00$ & $71.0 \pm 0.00$ & $68.0 \pm 0.05$ \\
\hline $\operatorname{COD}\left(\mathrm{mg} \mathrm{L}^{-1}\right)$ & $11.2 \pm 0.00$ & $11.8 \pm 0.00$ & $26.1 \pm 0.00$ & $22.8 \pm 0.05$ \\
\hline
\end{tabular}

Table 2. The physical and chemical characters of wastewater sample before and after cultivation of Chlorella $\mathrm{sp}$

\begin{tabular}{|c|c|c|c|}
\hline Parameters & $\begin{array}{l}\text { Before cultivation } \\
\text { of Chlorella }\end{array}$ & $\begin{array}{l}\text { After cultivation } \\
\text { of Chlorella }\end{array}$ & $\begin{array}{l}\text { Removal } \\
\text { rates }(\%)\end{array}$ \\
\hline $\mathrm{pH}$ & 7.74 & 8.10 & \\
\hline Conductivity (mS) & $4.55 \pm 0.01$ & $2.21 \pm 0.02$ & 51.43 \\
\hline T.D.S. $\left(\mathrm{g} \mathrm{L}^{-1}\right)$ & $2.76 \pm 0.01$ & $1.55 \pm 0.00$ & 43.84 \\
\hline Dissolved $\mathrm{O}_{2}\left(\mathrm{~g} \mathrm{~L}^{-1}\right)$ & $4.00 \pm 0.02$ & $6.00 \pm 0.05$ & -50.00 \\
\hline Alkalinity $\left(\mathrm{mg} \mathrm{L}^{-1}\right)$ & $129 \pm 0.01$ & $225 \pm 0.05$ & -74.41 \\
\hline Chloride $\left(\mathrm{mg} \mathrm{L}^{-1}\right)$ & $538 \pm 0.15$ & $500 \pm 0.02$ & 7.06 \\
\hline Nitrate-N $\left(\mathrm{mg} \mathrm{L}^{-1}\right)$ & $3.74 \pm 0.02$ & $1.84 \pm 0.02$ & 50.80 \\
\hline Phosphate-P (mg L $\left.{ }^{-1}\right)$ & $2.75 \pm 0.15$ & $1.06 \pm 0.02$ & 61.45 \\
\hline Sodium $\left(\mathrm{mg} \mathrm{L}^{-1}\right)$ & $315 \pm 0.00$ & $288 \pm 0.00$ & 8.57 \\
\hline Potassium $\left(\mathrm{mg} \mathrm{L}^{-1}\right)$ & $21.0 \pm 0.00$ & $12.0 \pm 0.00$ & 42.86 \\
\hline Calcium $\left(\mathrm{mg} \mathrm{L}^{-1}\right)$ & $158 \pm 0.02$ & $55.0 \pm 0.15$ & 65.19 \\
\hline Magnesium $\left(\mathrm{mg} \mathrm{L}^{-1}\right)$ & $68.0 \pm 0.05$ & $35.0 \pm 0.02$ & 48.52 \\
\hline $\operatorname{COD}\left(\mathrm{mg} \mathrm{L}^{-1}\right)$ & $22.8 \pm 0.05$ & $30.2 \pm 0.12$ & -32.46 \\
\hline
\end{tabular}

Table 3. The chemical composition of Chlorella vulgaris expressed on a dry weight $(\%)$

\begin{tabular}{lr}
\hline Parameters & Concentrations (\%) \\
\hline Total protein & 54.0 \\
Total carbohydrates & 18.6 \\
Total lipids & 30.5 \\
Nucleic acid & 3.5 \\
\hline
\end{tabular}

Table 4. The Biodiesel production ( $\%$ of dry weight) and Sediments (after algal biodiesel extraction) in Chlorella vulgaris

\begin{tabular}{lr}
\hline Parameters & Concentrations (\%) \\
\hline Biodiesel production (\% of dry weight) & 72.54 \\
Sediments (glycerine) (after algal & 32.52 \\
biodiesel extraction) & \\
\hline
\end{tabular}

Regarding to the biodiesel production from the tested alga the data of this investigation performed that the extracted oil seemed to be higher in compare to the other investigation (Ramachandra et al., 2009; Hossain and Salleh, 2008), Table 4. It seems biodiesel can be produced from macro algae though it contains lower lipid content than micro algae (Sharif et al., 2008).

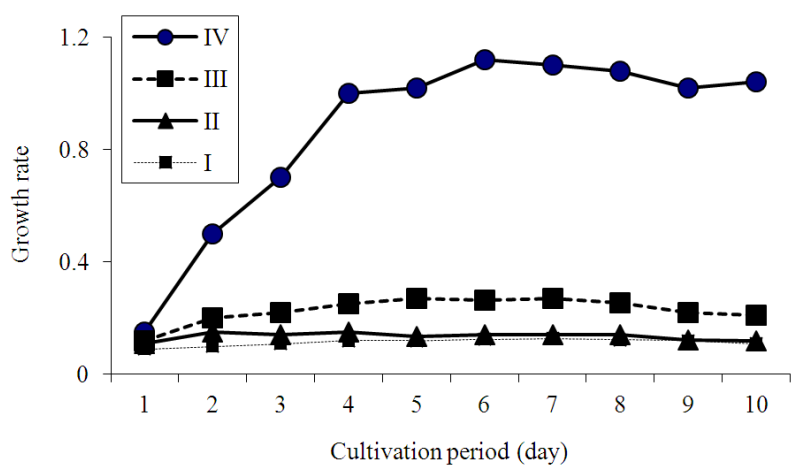

Fig. 2. Growth curves of the green alga Chlorella vulgaris grown in waste water

On other hand, sediment were also higher in Chlorella vulgaris than its recorded on other algal species (Ramachandra et al., 2009; Sharif and Salleh, 2008; Hossain and Salleh, 2008). Sharif et al. (2008) reported that algal oil and biodiesel (ester) production was higher in Oedogonium than Spirogyra sp. However, biomass (after oil extraction) was higher in Spirogyra than Oedogonium sp.

Biodiesel can be produced from macro algae because of lipid contents. Sijtsma and Swaaf (2004) stated that Docosahexaenoic Acid (DHA) was a polyunsaturated fatty acid composed of 22 carbon atoms and six double bonds that belonged to the socalled $\mathrm{w}-3$ group. Vincecate (2006) suggested that seaweeds contain about 5.5\% oil. Heterotrophic growth of certain marine eukaryotes, such as the microalgae, is enhanced in this medium. The samples harvested from these examples produce lipid fractions containing Omega-3 fatty acids. After extraction and esterification to form the methyl esters, gas chromatographic analyses show that the w-3 fatty acids may constitute as much as $10-50 \%$ of the total fatty acid fraction. Spolaore et al. (2006) evaluated that 
microalgae can provide several different types of renewable biofuels. Many researchers reported that biodiesel was derived from microalgal oil (Thomas, 2006; Sharif et al., 2008). Our results indicate that biodiesel can be produced from Chlorella vulgaris. In this way algae can be used as renewable energy.

\section{CONCLUSION}

Microalgal cultures offer an interesting alternative for waste water treatment because they provide a tertiary biotreatment coupled with the production of potentially valuable biomass, which can be used for several purposes. Microalgae have the potential to generate significant quantities of biomass and oil suitable for conversion to biodiesel. This study was undertaken to evaluate the remediation of wastewater by the green alga Chlorella vulgaris and the potential of these alga (biomass) to produce sustainable biofuel. The data indicted that cultivation of green alga Chlorella vulgaris on wastewater has a positive effect on removal the major inorganic elements form the wastewater. Biodiesel can be produced from Chlorella vulgaris. The Chlorella vulgaris can be used for remediation of wastewater and the producing biomass can be used as source of renewable energy.

\section{ACKNOWLEDGEMENT}

We thank Deanship of Scientific Research, King Faisal University and the Deanship members for financial support (Grant No: 110109).

\section{REFERENCES}

Abdel-Satar, A.M. and A. Elewa, 2001. Water quality and Environmental assessments of the River Nile at Rosette branch. Proceeding of the 2nd Conference and Exhibition for Life and Environment, Apr. 3-5, Alexandria, pp: 136-164.

Adams, V.D., 1991. Water and Wastewater Examination Manual. 1st Edn., Chelsea: Lewis Publishers, INC. USA., pp: 247.

Brune, D.E., T.J. Lundquist and J.R. Benemann, 2009. Microalgal biomass for greenhouse gas reductions: Potential for replacement of fossil fuels and animal feeds. J. Environ. Eng., 135: 1136-1144. DOI: 10.1061/(ASCE)EE.1943-7870.0000100

Chinnasamy, S., A. Bhatnagar, R.W. Hunt and K.C. Das, 2010. Microalgae cultivation in a wastewater dominated by carpet mill effluents for biofuel applications. Bioresource Technol., 101: 3097-3105. DOI: 10.1016/j.biortech.2009.12.026
Chisti, Y., 2008. Biodiesel from microalgae beats bioethanol. Trends Biotechnol., 26: 126-131. DOI: 10.1016/j.tibtech.2007.12.002

De-Bashan, L.E. and Y. Bashan, 2010. Immobilized microalgae for removing pollutants: Review of practical aspects. Bioresource Technol., 101: 16111627. DOI: $10.1016 /$ j.biortech.2009.09.043

Dismukes, G.C., D. Carrieri, N. Bennette, G.M. Ananyev and M.C. Posewitz, 2008. Aquatic phototrophs: Efficient alternatives to land-based crops for biofuels. Curr. Opin. Biotechnol., 19: 235-240. DOI: 10.1016/j.copbio.2008.05.007

Fathi, A.A., H.M. Abdelzaher, R. Flower, M. Ramdani and M, Kraiem, 2001. Phytoplankton communities of North African wetland lakes: The CASSARINA Project. Aquatic Ecol., 35: 303-318. DOI: 10.1023/A:1011988722774

Godos, I.D., S. Blanco, P.A. García-Encina, E. Becares and R. Munozm, 2009. Long-term operation of high rate algal ponds for the bioremediation of piggery wastewaters at high loading rates. Bioresource Technol., 100: 4332-4339. DOI: 10.1016/j.biortech.2009.04.016

Golterman, H.L. and R.S. Clymo, 1971. Methods for Chemical Analysis of Fresh Waters. 1st Edn., Blackwell, Oxford, pp: 166.

Hossain, A.B.M.S. and A. Salleh, 2008. Biodiesel fuel production from algae as renewable energy. Am. J. Biochem. Biotechnol., 4: 250-254. DOI: 10.3844/ajbbsp.2008.250.254

Kong, Q.X., L. Li, B. Martinez, P. Chen and R. Ruan, 2010. Culture of microalgae Chlamydomonas reinhardtii in wastewater for biomass feedstock production. Appl. Biochem. Biotechnol., 160: 9-18. DOI: $10.1007 / \mathrm{s} 12010-009-8670-4$

Kuhl, A., 1962. Zur physiologie der Speicherung Kondensierter anorganischer Phosphate in Chlorella. Vorlrag Bot. Hrsg. Deut. Botan. Ges., 1: 157-166.

Lowry, O.H., N.J. Rosenbroug, A.F. Farr and R.J. Randall, 1951. Protein measurement with the Folin phenol reagent. J. Biol. Chem., 193: 265-275. PMID: 14907713

Moore, S. and W.H. Stein, 1948. Photometric ninhydrin method for use in the chromatography of amino acids. J. Biol. Chem., 17: 367-388. PMID: 18886175

Mulbry, W., S. Kondrad, C. Pizarro and E. KebedeWesthead, 2008. Treatment of dairy manure effluent using freshwater algae: Algal productivity and recovery of manure nutrients using pilot-scale algal turf scrubbers. Bioresource Technol., 99: 8137-8142. DOI: $10.1016 /$ j.biortech.2008.03.073 
Munoz, R. and B. Guieysse, 2008. Algal-bacterial processes for the treatment of hazardous contaminants: A review. Water Res., 40: 2799-2815. DOI: $10.1016 /$ j.watres.2006.06.011

Olguin, E.J., 2003. Phycoremediation: Key issues for cost-effective nutrient removal processes. Biotechnol. Adv., 22: 81-91. DOI: 10.1016/S07349750(03)00130-7

Olgun, H., N. Ceviz and B. Ozkan, 2003. A case of dilated cardiomyopathy due to nutritional vitamin D deficiency rickets. Turkish J. Pediatrics, 45: 152-154.

Oswald, W.J. and C.G. Golueke, 1960. Biological transformation of solar energy. Adv. Applied Microbiol., 2: 223-262. PMID: 13731568

Pittman, J.K., Dean, A.P. and O. Osundeko, 2010. The potential of sustainable algal biofuel production using wastewater resources. Bioresource Technol. DOI: 10.1016/j.biortech.2010.06.035

Pizarro, C., W. Mulbry, D. Blersch and P. Kangas, 2006. An economic assessment of algal turf scrubber technology for treatment of dairy manure effluent. Ecol. Eng., 26: 321-327. DOI: 10.1016/j.ecoleng.2005.12.009

Ramachandra, T.V., M. Durga Madhab and B. Karthick, 2009. Milking diatoms for sustainable energy: Biochemical engineering versus gasoline-secreting diatom solar panels. Ind. Eng. Chem. Res., 48: 87698788. DOI: $10.1021 / \mathrm{ie} 900044 \mathrm{j}$

Rawat, I., R. Ranjith Kumar, T. Mutanda and F. Bux, 2011. Dual role of microalgae: Phycoremediation of domestic wastewater and biomass production for sustainable biofuels production. Applied Energy, 88: 3411-3424. DOI: 10.1016/j.apenergy.2010.11.025

Roe, J.H., 1955. The determination of sugar in blood and spinal fluid with anthrone reagent. J. Biol. Chem., 212: 335-343. PMID: 13233235
Sharif, H. and A.B.M. Salleh, 2008. Biodiesel fuel production from algae as renewable energy. Am. J. Biochem. Biotechnol., 4: 250-254.

Sharif, H.A.B.M., S. Aishah, N.B. Amru, C. Partha and N. Mohd, 2008. Biodiesel fuel production from algae as renewable energy. Am. J. Biochem. Biotechnol., 4: 250-254. DOI: 10.3844/ajbbsp.2008.250.254

Sijtsma, L. and M.E. Swaaf, 2004. Biotechnological production and applications of the $\omega-3$ polyunsaturated fatty acid docosahexaenoic acid. Applied Microbiol. Biotechnol., 64: 146-153. DOI: 10.1007/s00253-003-1525-y

Spolaore, P., C. Joannis-Cassan, E. Duran and A. Isambert, 2006. Commercial applications of microalgae. J. Biosci. Bioeng., 101: 87-96. PMID: 16569602

Stephens, E., I.L. Ross, Z. King, J.H. Mussgnug and O. Kruse et al., 2010. An economic and technical evaluation of microalgal biofuels. Nat. Biotechnol., 28: 126-128. DOI: $10.1038 /$ nbt0210-126

Strickland, J.D.H. and T.R. Parsons, 1972. A Practical Handbook of Seawater Analysis. 2nd Edn., Fisheries Research Board of Canada, Ottawa, ISBN-10: 0660115964, pp: 310.

Thomas, F.R., 2006. Algae for liquid fuel production oakhaven permaculture center. Permaculture Activist, 59: 1-2.

Vincecate, G., 2006. Any Seaweed with more than 5.5\% Oil? Sci. Biol.

Wang, L., M. Min, L. Yecong, C. Paul and C. Yifeng et al., 2010. Cultivation of green algae Chlorella sp. in different wastewaters from municipal wastewater treatment plant. Applied Biochem. Biotechnol. DOI: 10.1007/s12010-009-8866-7 